\title{
PERAMALAN INDEKS HARGA SAHAM GABUNGAN (IHSG) DENGAN METODE RADIAL BASIS FUNCTION NEURAL NETWORK MENGGUNAKAN GUI MATLAB
}

\author{
Rizki Brendita Br Tarigan ${ }^{1}$, Hasbi Yasin ${ }^{2}$, Alan Prahutama ${ }^{3}$ \\ 1,2,3 Departemen Statistika, Fakultas Sains dan Matematika, Universitas Diponegoro \\ e-mail : rizkitrg@gmail.com
}

\begin{abstract}
Capital market Indonesia is one of the important factors in the development of the national economy, proved to have many industries and companies that use these institutions as a medium to absorb investment to strengthen its financial position. The recent years, Jakarta Composite Index (JCI) in Capital Market tend to strengthen. JCI data are the time series data obtained from the past to predict the future with caracteris tics of JCI data are non stationary and non linier. Neural network is a computational method that imitate the biological neural network. There are several types of methods that can be used in neural network that is: Radial Basis Function Neural Network (RBFNN) Generalized Regression Neural Network (GRNN), dan Probabilistic Neural Network (PNN). Model of Radial Bas is Function Neural Network is suitable for time series data. This model has a network architecture in the form of input layer, hidden layer and output layer. This research is done with the help of GUI as a computation tool. The results of analysis by using GUI conducted on the size sample of data as much as 1211 taken as 100 the data thus obtained value of 2315,6 MSEtraining and training MAPEvalue of $0,72 \%$, while for the testing of 28886,7 MSEand MAPEtesting value is $0,70 \%$. Based on the results of forecasting, JCI values on January 02, 2018 until January 08, 2018 at 6499,922 every day.
\end{abstract}

Keywords: Radial Basis Function NeuralNetwork(RBFNN), Jakarta Composite Index(JCI), MSE, MAPE, Time Series, GUI.

\section{PENDAHULUAN}

Berdasarkan Badan Pusat Statistik Indonesia (2018), tentang ekonomi triwulan Indonesia IV 2017, perekonomian Indonesia tahun 2017 tumbuh menjadi 5,07\% dibanding capaian tahun 2016 sebesar 5,03\%. Pertumbuhan tersebut dipengaruhi oleh sisi produksi dan pengeluaran. Pasar modal di Indonesia merupakan salah satu faktor penting dalam pembangunan perekonomian nasional, terbukti telah banyak industri dan perusahaan yang menggunakan institusi ini sebagai media untuk menyerap investasi dan media untuk memperkuat posisi keuangannya. Salah satu indikator utama yang mencerminkan kinerja pasar modal di Indonesia saat sedang mengalami peningkatan (bullish) atau sedang mengalami penurunan (bearish) adalah indeks harga saham gabungan (IHSG). Karena IHSG ini mencatat pergerakan harga saham dari semua sekuritas yang tercatat di Bursa Efek Indonesia, pergerakan IHSG menjadi perhatian penting bagi semua investor di Bursa Efek Indonesia, sebab pergerakan IHSG ini akan mempengaruhi sikap para investor apakah akan membeli, menahan ataukah menjual sahamnya (Wijaya dan Sasi, 2015).

Data IHSG merupakan data time series yang diperoleh dari masa lalu untuk memprediksi masa yang akan datang. Prediksi data IHSG perlu dilakukan untuk mengetahui besar nilai diwaktu yang akan datang sehingga investor akan mengetahui kebijakan yang akan diambil nantinya. Salah satu metode yang digunakan untuk memprediksi suatu nilai adalah dengan menggunakan NeuralNetwork. NeuralNetwork merupakan salah satu metode statistika non-parametrik yang dapat digunakan untuk mengestimasi data tanpa harus memenuhi suatu asumsi. Neural network atau jaringan syaraf tiruan adalah suatu metode komputasi yang meniru sistem jaringan sarafbiologi. Ada beberapa jenis metode yang dapat digunakan dalam Neural Network antara lain : Radial Basis Function Neural Network $(R B F N N)$ untuk data time series, Generalized Regression Neural Network (GRNN) untuk 
data regresi, dan Probabilistic Neural Network (PNN) untuk data klasifikasi. Dalam penelitian ini metode yang digunakan untuk meramalkan nilai IHSG adalah RBFN. Pada metode RBFNN terdapat dua fungsi untuk membentuk jaringan syaraf basis radial yaitu newrbe dan newrb. Dalam penelitian ini penulis menggunakan fungsi newrb karena cenderung lebih sedikit (efektif) disbanding fungsi newrbe.

\section{TINJAUAN PUSTAKA}

\subsection{Pengertian Pasar Modal}

Menurut Fahmi (2015) Pasar modal adalah tempat dimana berbagai pihak khususnya perusahaan menjual saham (stock) dan obligasi (bond) dengan tujuan dari hasil penjualan tersebut nantinya akan di pergunakan sebagai tambahan dana untuk memperkuat modal perusahaan.

\subsection{Indeks Harga Saham}

Indeks harga saham adalah suatu indikator yang menunjukkan pergerakan harga saham. Indeks berfungsi sebagai indikator tren pasar, artinya pergerakan indeks menggambarkan kondisi pasar pada suatu saat, apakah pasar sedang aktif atau lesu (Martalena dan Maya, 2011). Pergerakan indeks menjadi indikator penting bagi para investor untuk menentukan apakah mereka akan menjual, menahan atau membeli suatu atau beberapa saham.

\subsection{Analis is Deret Waktu}

Data deret waktu merupakan sekelompok pengamatan yang diperoleh pada titik waktu yang berbeda dengan selang waktu yang sama dan barisan data diasumsikan saling berhubungan satu sama lain (Box dan Jenkins, 1994).

\subsection{Fungsi Autokore lasi (ACF)}

Menurut Soejoeti (1987), autokorelasi pada lag $k$ dapat didefinisikan sebagai:

$$
\rho_{k}=\frac{\operatorname{Cov}\left(Z_{t}, Z_{t+k}\right)}{\sqrt{\operatorname{Var}\left(Z_{t}\right)} \sqrt{\operatorname{Var}\left(Z_{t+k}\right)}}
$$

Data $\left\{Z_{t}\right\}$ yang stasioner akan mempunyai nilai mean $E\left\{Z_{t}\right\}=\mu$, dan variansi $\operatorname{Var}\left(Z_{t}\right)=E$ $\left(Z_{t}-\mu\right)^{2}=\sigma^{2}$ yang artinya mempunyai nilai-nilai yang konstan, maka kovariansi Cov $\left(Z_{t}, Z_{t+k}\right)$ dapat dituliskan sebagai:

$$
\operatorname{Cov}\left(Z_{t}, Z_{t+k}\right)=E\left[\left(Z_{t}-\mu\right)\left(Z_{t+k}-\mu\right)\right]=\gamma_{k}
$$

dengan $\operatorname{Var}\left(Z_{t}\right)=\operatorname{Var}\left(Z_{t+k}\right)=\gamma_{0}$, sehingga didapatkan:

$$
\rho_{k}=\frac{\gamma_{k}}{\gamma_{0}}
$$

Menurut Wei (2006), untuk suatu proses yang stasioner, fungsi autokovariansi $\gamma_{k}$ dan fungsi autokorelasi $\rho_{k}$ memenuhi sifat:

1. $\gamma_{0}=\operatorname{Var}\left(Z_{t}\right), \rho_{0}=1$

2. $\left|\gamma_{k}\right| \leq \gamma_{0},\left|\rho_{k}\right| \leq 1$

3. $\gamma_{k}=\gamma_{-k}, \rho_{k}=\rho_{-k}$, untuk semua nilai $\mathrm{k}$.

Matriks autokorelasi suatu runtun waktu stasioner yang panjangnya $\mathrm{k}$ dalam Soejoeti (1987) adalah sebagai berikut: 


$$
\stackrel{P}{\sim} k=\left[\begin{array}{ccccc}
1 & \rho_{1} & \rho_{2} & \cdots & \rho_{k-1} \\
\rho_{1} & 1 & \rho_{1} & \cdots & \rho_{k-2} \\
\rho_{2} & \rho_{1} & 1 & \cdots & \rho_{k-3} \\
\cdot & \cdot & \cdot & \cdots & \cdot \\
\cdot & \cdot & \cdot & \cdots & \cdot \\
\cdot & \cdot & \cdot & \cdots & \cdot \\
\rho_{k-1} & \rho_{k-2} & \rho_{k-3} & \cdots & 1
\end{array}\right]
$$

\subsection{Fungsi Autokore lasi Parsial (PACF)}

Menurut Wei (2006), Fungsi Autokorelasi Parsial (PACF) dapat dinyatakan sebagai:

$$
\emptyset_{k k}=\operatorname{Corr}\left(Z_{t}, Z_{t+k} \mid Z_{t+1}, \cdots, Z_{t+k-1}\right)
$$

Autokorelasi parsial dapat diperoleh dari model regresi, dimana variabel dependen $Z_{t+k}$ dari proses yang stasioner pada lag $k$, sehingga variabel $Z_{t+k-1}, Z_{t+k-2}, \cdots, Z_{t}$, dapat ditulis sebagai berikut:

$$
Z_{t+k}=\emptyset_{k 1} Z_{t+k-1}+\emptyset_{k 2} Z_{t+k-2}+\cdots+\emptyset_{k k} Z_{t}+a_{t+k}
$$

dimana $\emptyset_{k i}$ merupakan parameter regresi ke-i untuk $\mathrm{i}=1,2, \cdots, \mathrm{k}$ dan $a_{t+k}$ merupakan residu dengan rata-rata nol dan tidak berkolerasi dengan $Z_{t+k-j}$ untuk $\mathrm{j}=1,2, \cdots, \mathrm{k}$.

Secara umum nilai fungsi autokorelasi parsial (PACF) pada lag ke-k adalah:

$$
\emptyset_{k k}=\frac{\left|\begin{array}{cccccc}
1 & \rho_{1} & \rho_{2} & \cdots & \rho_{k-2} & \rho_{1} \\
\rho_{1} & 1 & \rho_{1} & \cdots & \rho_{k-3} & \rho_{2} \\
\vdots & \vdots & \vdots & \ddots & \vdots & \vdots \\
\rho_{k-1} & \rho_{k-2} & \rho_{k-3} & \cdots & \rho_{1} & \rho_{k}
\end{array}\right|}{\left|\begin{array}{cccccc}
1 & \rho_{1} & \rho_{2} & \cdots & \rho_{k-2} & \rho_{k-1} \\
\rho_{1} & 1 & \rho_{1} & \cdots & \rho_{k-3} & \rho_{k-2} \\
\vdots & \vdots & \vdots & \ddots & \vdots & \vdots \\
\rho_{k-1} & \rho_{k-2} & \rho_{k-3} & \cdots & \rho_{1} & 1
\end{array}\right|}
$$

\subsection{Neural Network}

Menurut Muis (2006), Jaringan syaraf tiruan sederhana pertama kali di perkenalkan oleh McCulloch dan Pitts di tahun 1943. McCulloch dan Pitts menyimpulkan bahwa kombinasi beberapa neuron sederhana menjadi sebuah sistem neural akan meningkatkan kemampuan komputasinya. Bobot dalam jaringan yang diusulkan oleh McCulloch dan Pitts diatur untuk melakukan fungsi logika sederhana. Jaringan syaraf tiruan adalah sistem pemroses informasi yang memiliki karateristik mirip dengan jaringan syaraf biologi.

Menurut Warsito (2009), dalam memproses informasi, jaringan syaraf manusia memiliki 3 elemen dasar sebagai berikut :

1. Himpunan penghubung

Himpunan penghubung merupakan himpunan unit-unit yang dihubungkan dengan suatu jalur koneksi. Jalur-jalur tersebut memiliki bobot yang berbeda. Bobot yang bernilai positif akan memperkuat sinyal sedangkan bobot yang bernilai negatif akan memperlemah sinyal. Jumlah, struktur dan pola hubungan antar unit-unit tersebut akan menentukan arsitektur jaringan yang berbentuk.

2. Fungsi Penjumlahan

Fungsi penjumlahan merupakan suatu unit yang akan menjumlahkan input-input sinyal yang sudah dikalikan dengan bobot masing-masing.

3. Fungsi Aktivasi

Fungsi aktivasi merupakan sebuah fungsi transfer yang berguna untuk menyesuaikan output yang dihasilkan oleh sistem jaringan syaraf sehingga sesuai dengan target. Fungsi aktivasi dapat digunakan sebagai dasar untuk mengubah bobot, yang dapat 
menjadikan jaringan menjadi lebih powerful. Fungsi aktivasi juga menghasilkan informasi yang akan dikirim ke neuron lain dengan bobot kedatangan tertentu. Dalam Radial Basis Function Neural Network (RBFN) fungsi aktivasi yang digunakan adalah Fungsi berbasis radial.

\subsection{Radial Basis Function Neural Network (RBFNN)}

Radial Basis Function Neural Network (RBFNN) adalah salah satu metode jaringan syaraf tiruan yang digunakan untuk menyelesaikan permasalahan time series. Pada matlab fungsi untuk membentuk jaringan syaraf basis radial adalah newrbe dan newrb. Jaringan yang terbentuk pada fungsi newrbe terdiri dari beberapa neuron dengan fungsi aktivasi radbas, dengan input $\mathrm{P}$ dan bobot pada lapisan tersembunyi $\mathrm{P}$ '. Sehingga apabila matriks input berisi $\mathrm{Q}$ vektor, maka pada lapisan tersembunyi juga akan berisi $\mathrm{Q}$ buah neuron. Sedangkan pada newrb, pada setiap iterasi akan dibentuk 1 neuron. Neuron yang memiliki total error terkecil akan diterima sebagai neuron baru. Kemudian error pada jaringan syaraf di cek ulang, apabila error jaringan sudah cukup kecil, makan iterasi dihentikan. Namun apabila error jaringan masih cukup besar, maka akan ditambahkan nauron berikutnya, demikian seterusnya. Sehingga pada newrb, jumlah neuron pada lapisan tersembunyi belum tentu sama dengan jumlah vektor input (Kusumadewi, 2004).

\subsection{Algoritma Radial Basis Function Neural Network}

Menurut Kusumadewi (2004), algoritma perhitungan Radial Basis Function Neural Network adalah sebagai berikut:

1. Mencari $\mathrm{D}_{i k}$ yaitu jarak Euclid.

$$
\mathrm{D}_{i k}=\left\|x_{i j}-x_{k j}\right\|=\sqrt{\sum_{j=1}^{p}\left(x_{i j}-x_{k j}\right)^{2}}
$$

dimana $i, k=1,2, \ldots, n$ dan $n$ adalah banyaknya amatan

$$
j=1,2, \ldots, p \text { dan } \mathrm{p} \text { adalah banyaknya variabel prediktor }
$$

2. Mencari $\varphi$ yaitu hasil aktivasi dengan fungsi basis radial dari jarak data dikalikan bias.

$$
\varphi_{i k}=e^{-\left(b 1 * D_{i k}\right)^{2}}
$$

3. Mencari bobot lapisan dan bobot bias lapisan, $\mathrm{w}_{\mathrm{i}}^{(2)}$ dan $b_{1}$ dengan menyelesaikan persamaan linier berikut yang dapat diselesaikan dengan metode Least Square.

$$
\begin{aligned}
& \varphi_{11} \mathrm{w}_{1}^{(2)}+\varphi_{12} \mathrm{w}_{2}^{(2)}+\cdots+\varphi_{1 n} \mathrm{w}_{\mathrm{n}}^{(2)}+b_{2}=\mathrm{d}_{1} \\
& \varphi_{21} \mathrm{w}_{1}^{(2)}+\varphi_{22} \mathrm{w}_{2}^{(2)}+\cdots+\varphi_{2 n} \mathrm{w}_{\mathrm{n}}^{(2)}+b_{2}=\mathrm{d}_{2} \\
& \vdots \\
& \varphi_{n 1} \mathrm{w}_{1}^{(2)}+\varphi_{n 2} \mathrm{w}_{2}^{(2)}+\cdots+\varphi_{n n} \mathrm{w}_{\mathrm{n}}^{(2)}+b_{2}=\mathrm{d}_{\mathrm{n}}
\end{aligned}
$$

Persamaan (1) jika disusun dalam bentuk matriks adalah sebagai berikut:

$$
\left[\begin{array}{ccccc}
\varphi_{11} & \varphi_{12} & \ldots & \varphi_{1 n} & 1 \\
\varphi_{21} & \varphi_{22} & \ldots & \varphi_{2 n} & 1 \\
\vdots & \vdots & \ddots & \vdots & \vdots \\
\varphi_{n 1} & \varphi_{n 2} & \ldots & \varphi_{n n} & 1
\end{array}\right]\left[\begin{array}{c}
\mathrm{w}_{1}^{(2)} \\
\mathrm{w}_{2}^{(2)} \\
\vdots \\
\mathrm{w}_{\mathrm{n}}^{(2)} \\
b_{2}
\end{array}\right]=\left[\begin{array}{c}
d_{1} \\
d_{2} \\
\vdots \\
d_{n}
\end{array}\right]
$$

Atau bisa dinotasikan sebagai berikut:

$$
\begin{array}{ccccc} 
& \mathbf{G} \mathbf{w}=\mathbf{d} \\
\text { dimana } & \mathbf{d}=\left[\begin{array}{llll}
d_{1} & d_{2} & \ldots & d_{n}
\end{array}\right]^{T} \\
& \mathbf{w}=\left[\begin{array}{llll}
w_{1} & w_{2} & \ldots & w_{n}
\end{array}\right]^{T}
\end{array}
$$




$$
\begin{aligned}
& \mathbf{G}=\varphi_{n n} \\
\text { sehingga } \quad \boldsymbol{w} & =\left(\mathbf{G}^{\mathrm{T}} \mathbf{G}\right)^{-1} \mathbf{G}^{\mathrm{T}} \mathbf{d}
\end{aligned}
$$

\subsection{Arsitektur Radial Basis Function Neural Network}

$\mathrm{P}_{\mathrm{i}}$ adalah

(p)

$\left\|D_{i}\right\|$

jarak

input

dengan

input ke-i

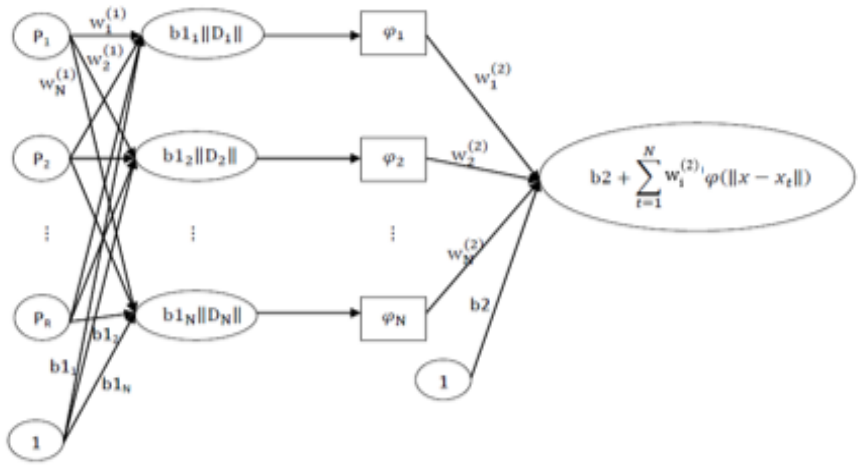

Output Layer

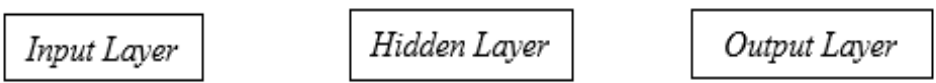

data input

adalah

antara

data

bobot

$\left(\mathrm{W} 1_{\mathrm{i}}\right)$

Dari gambar arsitektur jaringan radial basis diatas dapat dilihat bahwa terdapat 3 lapisan struktur radial basis function yaitu :

1. Input layer

Adalah bagian dari rangkaian jaringan syaraf tiruan radial basis function sebagai masukan untuk melakukan proses pertama. Input layer ini membaca data dari faktor luar yaitu keluaran plant (unit sensor) dan nilai yang kita kehendaki

2. Hidden layer

Pada bagian ini terjadi aktivitas perumusan dalam pembentukan sistem algoritma yang digunakan dalam jaringan radial basisifunction. Layer (lapisan) kedua adalah lapisan tersembunyi dari dimensi yang lebih tinggi, yang melayani suatu tujuan pada fungsi basis dan bobotnya dengan nilai yang berbeda.

3. Output Layer

Hasil dari penjumlahan dari perkalian antara bobot dengan fungsi basis akan menghasilkan keluaran yang disebut output layer.

\subsection{GUI Matlab}

Menurut Sugiharto (2006), GUI Matlab merupakan sebuah graphical user interface (GUI) yang dibangun dengan obyek grafis seperti tombol (button), kotak teks, slider, sumbu (axes), maupun menu. GUI Matlab memiliki banyak keunggulan tersendiri, antara lain:

1. GUI Matlab banyak digunakan dan cocok untuk aplikasi-aplikasi berorientasi sains, sehingga banyak peneliti atau mahasiswa, baik S1,S2 maupun S3 menggunakan GUI matlab untuk menyelesaikan riset atau tugas akhirnya.

2. Matlab memiliki banyak fungsi built in yang siap digunakan dan pemakai tidak perlu repot membuatnya sendiri

3. Ukuran file, baik FIG-File maupun M-File , yang dihasilkan relatif kecil

4. Kemampuan grafisnya cukup andal dan tidak kalah dibandingkan bahasa pemograman lainnya. 


\section{METODE PENELITIAN}

\subsection{Jenis dan Sumber Data}

Data yang digunakan pada penelitian ini adalah data indeks harga saham (IHSG) selama 5 tahun terakhir, mulai periode 2 Januari 2013 hingga 29 Desember 2017. Data tersebut merupakan data sekunder yang diperoleh dari https://finances.yahoo.com/. Jumlah data yang digunakan sebanyak 1211 data.

\subsection{Variabel Penelitian}

Variabel yang digunakan dalam penelitian ini adalah nilai IHSG per hari yang di ambil dalam jangka waktu kurang lebih selama 5 tahun terakhir.

\subsection{Alat Analis is Data}

Pada penelitian ini, output yang dihasilkan merupakan hasil pengolahan data dengan menggunakan software statistika, yaitu Ms. Excel, Minitab dan MATLAB R2012b.

\subsection{Langkah-langkah Penelitian}

Adapun langkah-langkah dalam penelitian dan analisis data adalah sebagai berikut:

1. Menginput data nilai IHSG

2. Menentukan lag input dengan menggunakan plot PACF

3. Membagi data berdasarkan data training dan data testing. Pada penelitian ini menggunakan $90 \%$ data training dan $10 \%$ data testing

4. Menentukan nilai spread. Pada penelitian ini nilai spread yang digunakan ialah mean dari data.

5. Memilih 100 data dari 1211 data

6. Menghitung jarak Euclidean $\left(\mathrm{D}_{\mathrm{ik}}\right)$

7. Menghitung nilai aktivasi $(\varphi)$

8. Menghitung bobot $\left(\mathrm{w}_{\mathrm{i}}\right)$

9. Mendapatkan MAPE dan MSE dari data training dan testing

10. Meramalkan data dari periode 02 januari 2018 sampai dengan 08 januari 2018

11. Menentukan kesimpulan

\section{HASIL DAN PEMBAHASAN}

\subsection{Menentukan Input Jaringan}

Pada pemodelan time series, data masa kini dipengaruhi oleh data masa lalu sehingga dalam hal ini data pada model Radial Basis Function Neural Network adalah data masa lalu (lag time) dan targetnya adalah data masa kini, sebagaimana terminologi autoregressif pada metode ARIMA Box-Jenkins (Warsito, 2009). Identifikasi lag sebagai komponen input didasarkan pada lag-lag yang memiliki nilai PACF terbesar. Berdasarkan identifikasi lag yang dapat dilihat pada Gambar 6 diperoleh 2 variabel lag yang akan dijadikan sebagai komponen data input, yaitu lag 1 dan 4 atau dapat dikatakan bahwa $X_{t}$ dipengaruhi oleh $X_{t-1}$ dan $X_{t-4}$.

\subsection{Membagi Data}

Setelah menentukan variabel input yang akan digunakan dari plot PACF, langkah selanjutnya adalah membagi data menjadi 2 , yaitu data training dan data testing. Dalam penelitian ini komposisi pembagian data yang digunakan adalah $90 \%$ data training untuk dan $10 \%$ untuk data testing. 


\subsection{Menentukan nilai spread}

Nilai spread yang digunakan dalam penelitian ini ialah dipilih melalui uji coba sampai mendapatkan hasil terbaik. Dari beberapa uji coba yang telah dilakukan dilihat hasil akhirnya, sehingga ditentukan nilai spread yang digunakan dalam program MATLAB adalah:

$$
\text { Spread=mean }(\mathrm{dt})
$$

\subsection{Pemilihan 100 data dari 1211 data}

Keunggulan dari fungsi newrb yaitu pemodelan tidak harus dilakukan dengan cara menghitung semua data atau dengan kata lain dapat menggunakan beberapa data untuk mendapatkan pemodelan yang diinginkan. Tidak ada aturan khusus untuk pemilihan berapa jumlah data yang akan digunakan. Pada perhitungan kali ini, penulis mengambil sebanyak 100 data dari total keseluruhan data.

\subsection{Menghitung jarak Euclid}

Menghitung $\mathrm{D}_{i, k}$ (jarak Euclid) yaitu $\left\|x_{i}-x_{k}\right\|$ untuk data training $i, k=$ $1,2, \ldots, 1086$ untuk perhitungan data teraining terhadap 100 data terpilih dan untuk data testing $i, k=1,2, \ldots, 121$ untuk perhitungan data testing terhadap 100 data terpilih. Adapaun rumus yang digunakan untuk menghitung jarak Euclid ialah :

\subsection{Menghitung nilai aktivasi}

$$
\mathrm{D}_{i k}=\sqrt{\sum_{j=1}^{n}\left(x_{i j}-x_{k j}\right)^{2}}
$$

Menghitung $\varphi$ yaitu nilai aktivasi dengan fungsi basis radial dari jarak data dikalikan bias.

$$
\varphi_{i k}=e^{-\left(\mathrm{b}_{1} * \mathrm{D}_{i k}\right)^{2}}
$$

Sebelum menghitung nilai dari fungsi aktivasi, terlebih dahulu dicari nilai dari $b_{1}$, yaitu sebagai berikut:

$$
\mathrm{b}_{1}=\frac{\sqrt{-\ln (0.5)}}{\text { spread }}=\frac{0,8325}{5034.751}=0,000165
$$

Setelah memperoleh nilai $b_{1}$ selanjutnya menghitung nilai aktivasi untuk data training dan testing dengan $\varphi_{i k}$

\subsection{Menghitung bobot}

Menghitung bobot lapisan $\left(\mathrm{w}_{\mathrm{i}}^{(2)}\right)$ dan bobot bias lapisan $\left(\mathrm{b}_{2}\right) .\left(\mathrm{w}_{\mathrm{i}}^{(2)}\right)$ dan $\mathrm{b}_{2}$ diperoleh dengan menyelesaikan persamaan linier berikut yang dapat diselesaikan dengan metode Least Square.

Persamaan linier untuk data training 1

$0,887272 w_{1}^{(2)}+0,890675 w_{2}^{(2)}+\cdots+0,975023 w_{100}^{(2)}+b_{2}=4392,38$

Persamaan linier untuk data training 2

$0,888711 w_{1}^{(2)}+0,892339 w_{2}^{(2)}+\cdots+0,518336 w_{100}^{(2)}+b_{2}=4362,93$

$\vdots$

Persamaan linier untuk data training 1086

$0,999764 w_{1}^{(2)}+1 w_{2}^{(2)}+\cdots+0,967546 w_{100}^{(2)}+b_{2}=5825,05$

Persamaan linier di atas jika disusun dalam bentuk matriks akan menjadi seperti berikut: 


$$
\left[\begin{array}{ccccc}
0,887272 & 0,890675 & \cdots & 0,975023 & 1 \\
0,888711 & 0,892339 & \cdots & 0,518336 & 1 \\
\vdots & \vdots & \ddots & \vdots & \vdots \\
0,999764 & 1 & \cdots & 0,967546 & 1
\end{array}\right]\left[\begin{array}{c}
w_{1}^{(2)} \\
w_{2}^{(2)} \\
\vdots \\
w_{100}^{2} \\
b_{2}
\end{array}\right]=\left[\begin{array}{c}
4392,38 \\
4362,93 \\
\vdots \\
5825,05
\end{array}\right]
$$

Dengan menggunakan least square maka diperoleh nilai bobot lapisan $\left(\mathrm{w}_{1}^{(2)}, \mathrm{w}_{2}^{(2)}, \ldots, \mathrm{w}_{100}^{(2)}\right.$ yaitu $\left.-2,39768 \times 10^{11}, 1,71122 \times 10^{11}, \ldots, 0\right)$. Nilai bobot bias lapisan $b_{2}$ yang diperoleh adalah sebesar $1,5869 \times 10^{7}$

\subsection{Menghitung Output}

Setelah melakukan semua perhitungan diatas langkah selanjutnya adalah menjumlahkan semua hasil dari perhitungan diatas, contoh perhitungan yang dilakukan ialah Menghitung nilai output pada data training

a. Output 1 data training

$$
a 2_{1}=\left(0,887272 \times\left(-2,39768 \times 10^{11}\right)+\left(0,890675 \times\left(1,71122 \times 10^{11}\right)+\cdots+\right.\right.
$$

$(0,975023 \times 0)+1,5869 \times 10^{7}=-65149,14695$

Proses perhitungan terus dilakukan sampai menghitung output 1086 data training

b. $\quad$ Output 1086 data training

$a 2_{1}=\left(0,999764 \times\left(-2,39768 \times 10^{11}\right)+\left(1 \times\left(1,71122 \times 10^{11}\right)\right)+\cdots+\right.$

$(0,967546 \times 0)+1,5869 \times 10^{7}=-2,82891 \times 10^{12}$

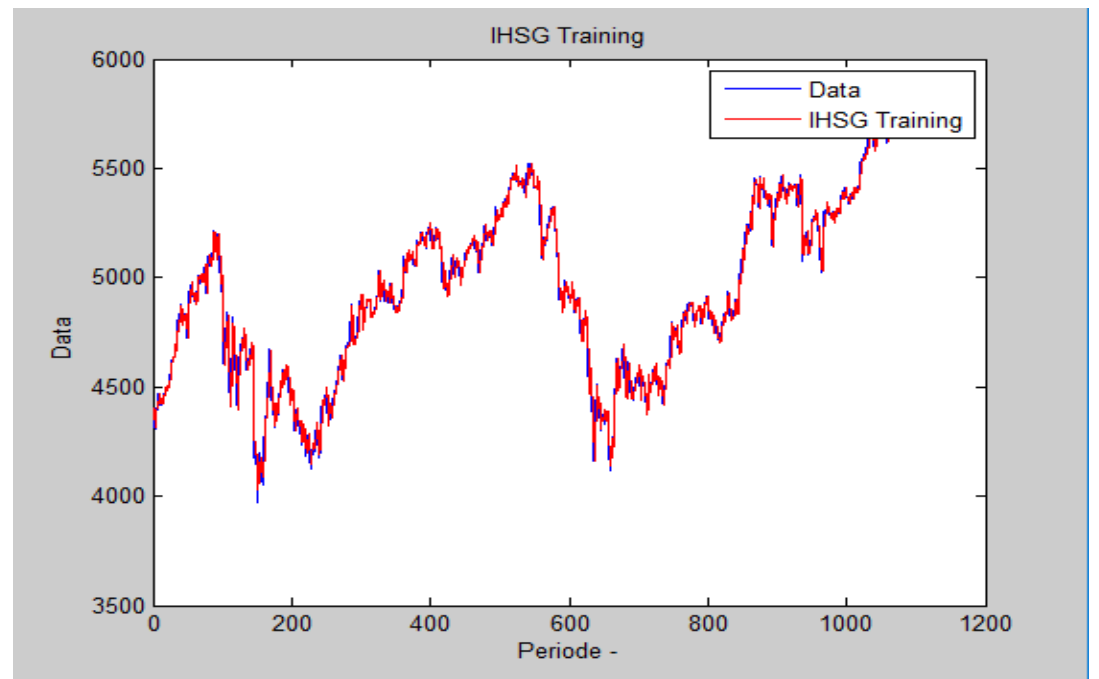

Gambar 1. Plot data Training

Dari perhitungan program MATLAB didapatkan nilai MSE training sebesar $2,3156 \times 10^{3}$ dan nilai MAPE-nya sebesar $0,72 \%$. Jadi dapat disimpulkan bahwa data training yang digunakan sudah cukup optimal.

Menghitung nilai output pada data testing

a. Output 1 data testing

$$
\begin{gathered}
a 2_{1}=\left(0,999519 \times\left(-2,39768 \times 10^{11}\right)\right)+\left(0,999807 \times\left(1,71122 \times 10^{11}\right)\right)+\cdots \\
+(0,963131 \times 0)+1,5869 \times 10^{7}=-63849,354
\end{gathered}
$$

Proses perhitungan terus dilakukan sampai menghitung output 121 data testing

b. Output 121 data testing

$$
\begin{aligned}
a 2_{1}= & \left(0,991425 \times\left(-2,3976 \times 10^{11}\right)\right)+\left(0,990134 \times\left(1,71122 \times 10^{11}\right)\right)+\cdots+ \\
& (0,924247 \times 0)+1,5869 \times 10^{7}=-63787,34421
\end{aligned}
$$




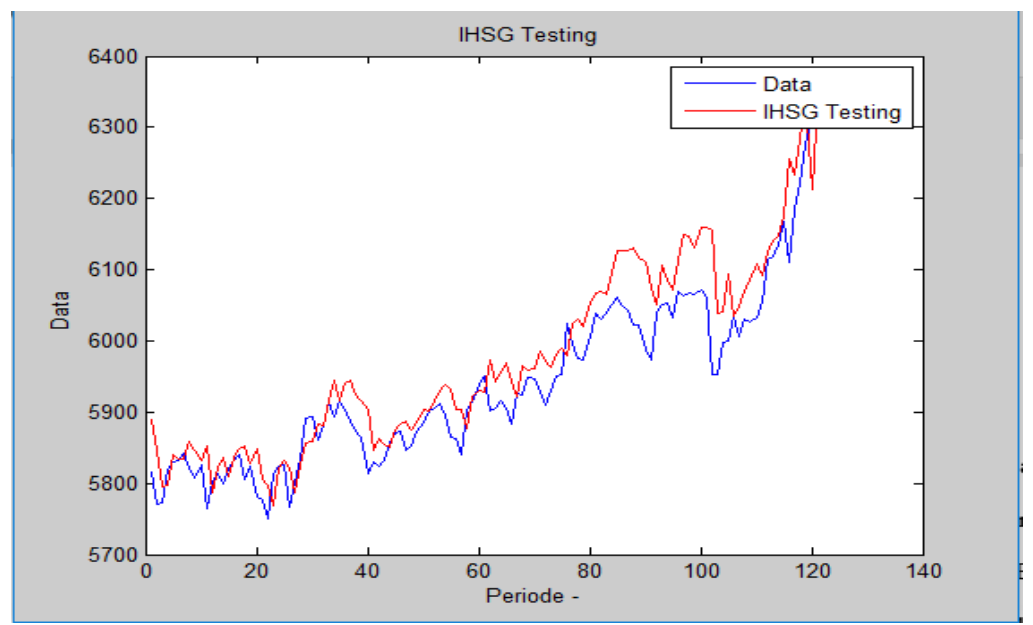

Gambar 2. Plot data Testing

Dari perhitungan tersebut, langkah akhir untuk mengetahui apakah data testing yang digunakan sudah optimal ialah dengan melihat nilai MSE dan MAPE-nya. Dari perhitungan program MATLAB didapatkan nilai MSE testing sebesar 2,886 $\times 10^{3}$ dan nilai MAPE-nya sebesar $0,70 \%$. Jadi dapat disimpulkan bahwa data testing yang digunakan sudah cukup optimal dan dapat digunakan perhitungan selanjutnya yaitu menghitung nilai peramalannya

\subsection{Peramalan Indeks Harga Saham Gabungan (IHSG)}

Peramalan data menggunakan metode Radial Basis Function Neural Network akan digunakan untuk memprediksi nilai indeks harga saham gabungan untuk jangka waktu 5 hari kerja kedepan

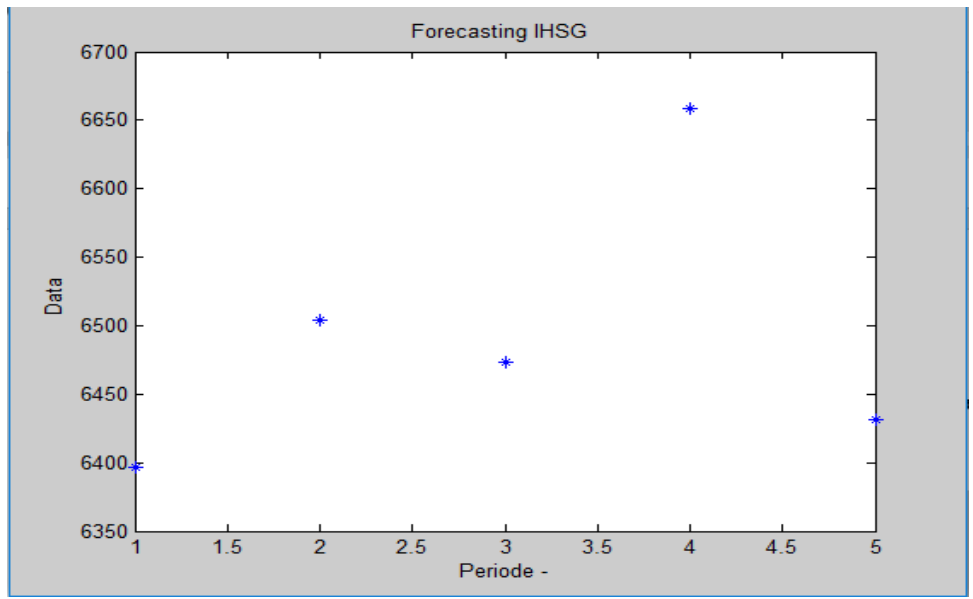

Gambar 3. Peramalan IHSG

Tabel 1. Nilai peramalan indeks harga saham gabungan

\begin{tabular}{ll}
\hline Periode & Peramalan IHSG \\
\hline 02 Januari 2018 & 6396,26955848746 \\
03 Januari 2018 & 6504,01907020621 \\
04 Januari 2018 & 6473,79592567496 \\
05 Januari 2018 & 6658,67190223746 \\
08 Januari 2018 & 6431,85158973746 \\
\hline
\end{tabular}




\subsection{Menggunakan GUI untuk peramalan Indeks Harga Saham Gabungan (IHSG) dengan metode Radial Basis Function Neural Network}

Tampilan untuk GUI RBFNN terdiri dari dua layar, layar pertama merupakan tampilan awalan GUI dan layar kedua merupakan layar untuk proses peramalan IHSG menggunakan GUI Matlab

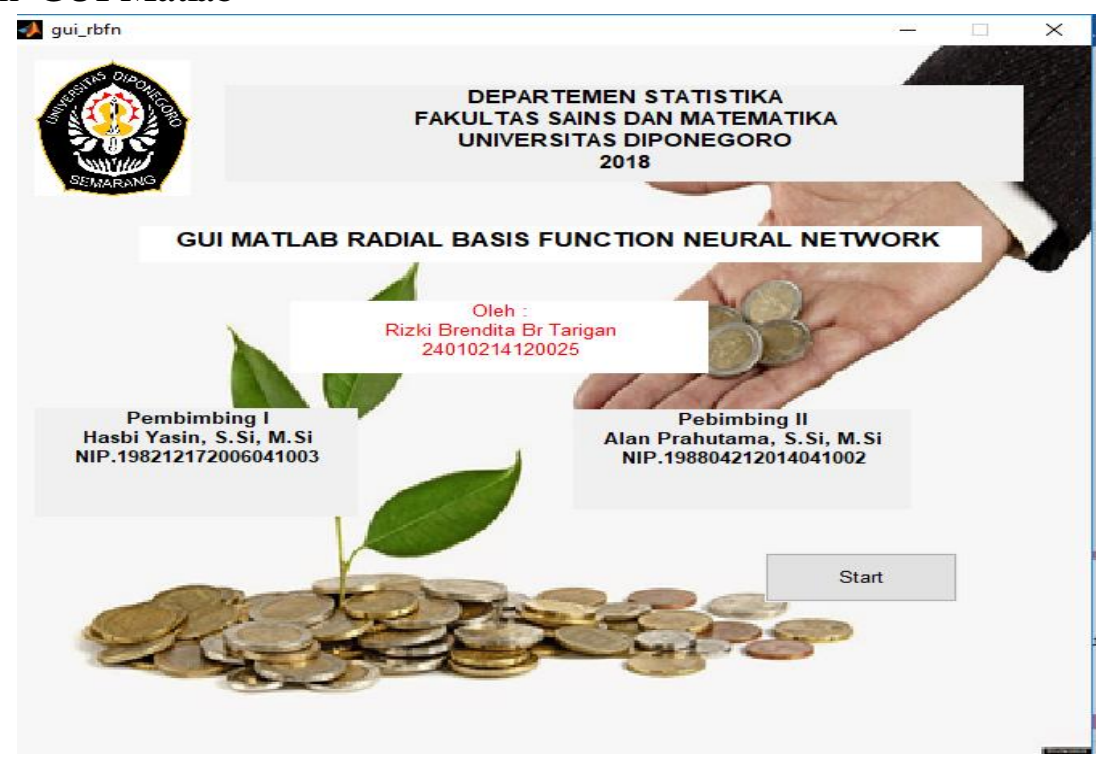

Gambar 4. Layar 1

Layar 1 merupakan tampilan awal untuk masuk ke layar 2, layar 1 terdiri atas nama penyusun, judul dan dosen pembimbing kemudian klik tombol start makan otomatis akan masuk ke layar 2.

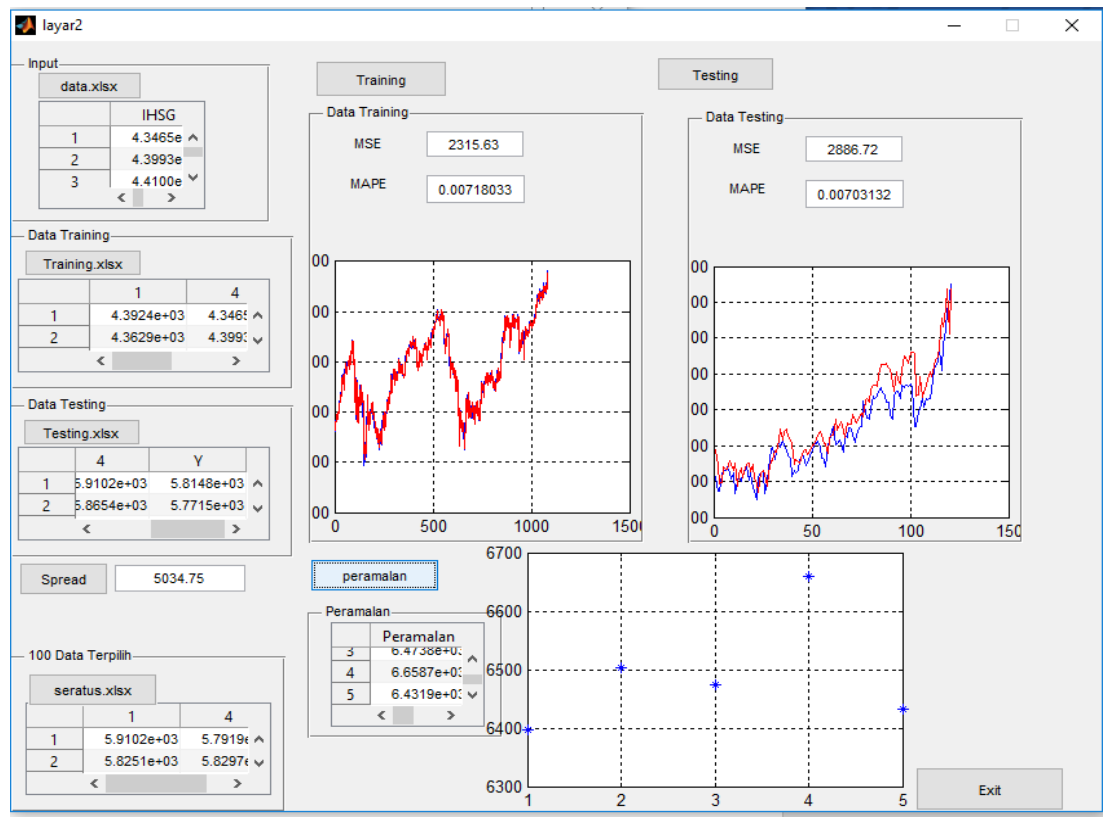

Gambar 4. Layar 2

Layar 2 merupakan proses pengolahan data sampai mendapatkan peramalan IHSG, proses dimulai dari menginput data IHSG, data training, data testing, 100 data terpilih, kemudian klik tombol spread, training, testing dan peramalan sehingga hasil peramalan dan grafiknya akan ditampilkan. 


\section{KESIMPULAN}

Berdasarkan pembahasan pada bab sebelumnya mengenai peramalan Indeks Harga Saham Gabungan (IHSG) menggunakan metode Radial Basis Function Neural Network, dapat disimpulkan bahwa:

1. Fungsi newrb pada Radial Basis Function Neural Network merupakan salah satu metode yang cocok digunakan untuk mengolah data dalam skala besar karena hanya dengan menggunakan beberapa data saja dapat diperoleh nilai peramalan, sehingga hal tersebut sangat efektif dan efesien.

2. Pada tahap pemodelan menggunakan metode Radial Basis Function Neural Network diperoleh nilai MSE training adalah 2,3156 $\times 10^{3}$ dan nilai MAPE adalah $0,72 \%$. Sedangkan untuk data testing, diperoleh nilai MSE-nya adalah $2,8867 \times 10^{3}$ dan nilai MAPE-nya adalah $0,70 \%$.

3. Berdasarkan nilai peramalan dapat disimpulkan bahwa indeks harga saham gabungan dalam waktu yang akan datang rata-rata 6492,922 perharinya.

4. GUI Radial Basis Function Neural Network dibuat melalui empat tahap yaitu merancang konsep dan tampilan, menyusun perintah (sintaks), meletakkan sintaks dan menyesuaikannya pada lembar komputasi GUI, serta finishing.

\section{DAFTAR PUSTAKA}

Badan Pusat Statistik. (2018). Ekonomi Indonesia Triwulan IV-2017 Tumbuh 5,19 Persen. Diakses 3 mei 2018, dari Badan Pusat Statistik https://www.bps.go.id/pressrelease/2018/02/05/1519/ekonomi-indonesia-triwulaniv-2017--tumbuh-5-19-persen.html

Bursa Efek Indonesia. 2018. Indeks Harga Saham. Diakses 26 Maret 2018, dari Bursa Efek Indonesia : http://www.idx.co.id/produk/indeks/

Box, G.E.P. and Jenkins, G.M. 1976. Time Series Analysis: Forecasting and Control. San Fransisco: Holden-day Inc.

Darmadji, T., \& Fakhruddin, H.M. (2011). Pasar Modal di Indonesia. Jakarta : Salemba Empat.

Fahmi I. 2012. Pengantar Pasar Modal. Bandung: Alfabeta.

Fausett. 1994. Fundamentals of Neural Networks. New Jersey: Prentice Hall.

Haykin, S. 1999. Neural Network: A Comprehensive Foundation. Inc, Prentice Hall.

Kusumadewi, S. 2004. Membangun Jaringan Syaraf Tiruan Menggunakan Matlab \& Excel Link. Graha Ilmu.

Mathworks. 2015. Creating Graphical User Interface. The Mathworks, Inc.

Martalena \& Maya, M. 2011. Pengantar Pasar Modal. Edisi Pertama, Penerbit Andi: yogyakarta

Markidakis, McGee, \& Wheelright. (1999). Metode dan Aplikasi Peramalan (Edisi Kedua ed.). (H.Suminto,Penerj.) Jakarta: Binarupa Aksara.

Muis S. 2006. Teknik Jaringan Syaraf Tiruan. Graha Ilmu.

Siang, J. J. 2005. Jaringan Syaraf Tiruan dan Pemrogramannya Menggunakan Matlab. Yogyakarta: Andi.

Soejoeti, Z. 1987. Analiss Runtun Waktu. Jakarta: Karunika, Universitas Terbuka.

Sugiharto, A. 2006. Pemograman GUI dengan MATLAB. Yogyakarta : Andi

Sumantoro. 1990. Pengantar tentang Pasar Modal di Indonesia. Jakarta : Ghalia Indonesia.

Suyatno. 2015. Prediksi Forex Menggunakan Model Neural Network. Download.portalgaruda.org, Vol 6, No 2.

Warsito, B. 2009. Kapita Selekta Statistika Neural Network. Semarang: BP UNDIP. 
Wahyuni,W., Khairani, S., \& Wenny, D. C. 2014. Pengaruh Indeks Harga Saham Global Terhadap Pergerakan Indeks Harga Saham Gabungan (IHSG) Di Bursa Efek Indonesia.eprints.mdp.ac.id.

Wijaya T.S.J., \& Agustin Sasi. 2015. Faktor-Faktor yang mempengaruhi nilai IHSG yang terdaftar di bursa efek Indonesia. ejournal.stiesia.ac.id, Vol 4, No 6.

Yahoo Finance. 2018. Data Indeks Harga Saham Gabungan Tahun 2012-2017. Diunduh 12 Maret 2018, dari Yahoo Finance : https:/finance.yahoo.com/ quote $/ \% 5 \mathrm{EJKSE} /$ history? $\mathrm{p}=\% 5 \mathrm{EJKSE}$ 